\title{
An Ecological Study On Water To Some Thermal Springs In Koya-Erbil Province, Iraq
}

\author{
Yadi O. M. Al-Barzingy Siraj M. Goran \\ Janan J. Toma
}

Department of Environmental Sciences / College of Science University of Salahaddin

\author{
Received \\ $.9 / 1 \cdot / 200 \wedge$
}

\author{
Accepted \\ 1 1 / 0 r / 2009
}

الخلاصة

بالرغم من نواجد عدد من الينابيع الحارة في العراق، لوحظ تواجد القليل من الدراسـات

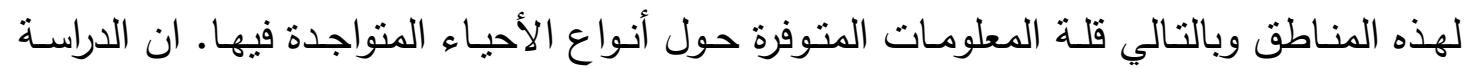

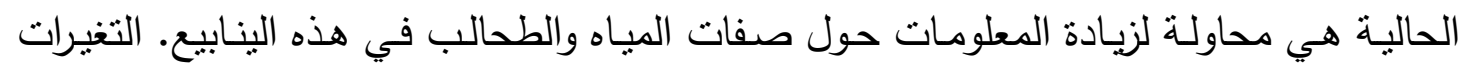
الثهرية في الصفات الفيزياوية والكيمياوية وتقدير وجود الطحالب تم دراستها في ينبوعي جلي

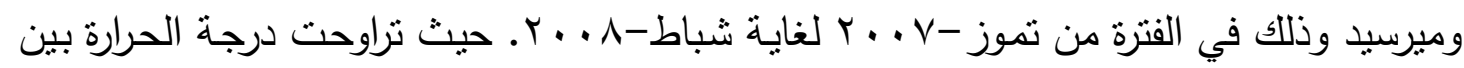

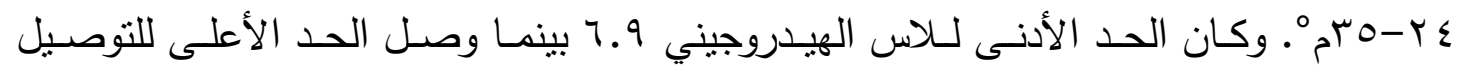

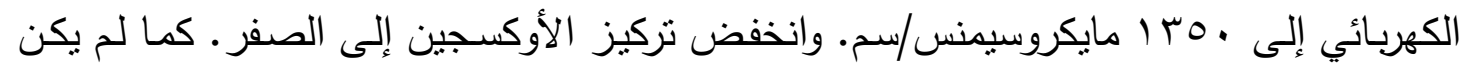

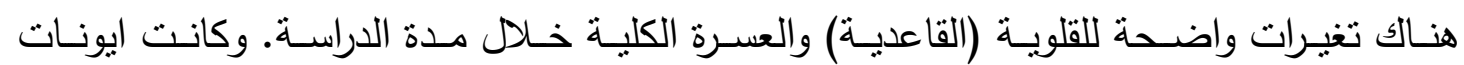
الكالسيوم والسلفات هي الغالبة على الايونات الموجبة والسالبة على التوالي. ولقد تم تتخيص r ب نوع من الطحالب، تميزت الطحالب الخضر المزرقة في وجودها على الأنواع الأخرى.

\begin{abstract}
In spite of existing a number of thermal springs in Iraq. A limited studies were observed to be found concerning it. Where there are a little information concerning their types of organisms. The present study is an attempt to expand springs water characteristics and algal occurrences.

Monthly variations in physico-chemicals variables and algae were studied in Mersaid and a Jale springs from July-2007 to February-2008. It was found that water temperature ranged from 24 to $35 \mathrm{C}^{\circ}$. Minimum value of $\mathrm{pH}$ was 6.9 and maximum value of electrical conductivity is $1350 \mu \mathrm{s} . \mathrm{cm}^{-1}$.Oxygen concentration was zero. No significant variations are found in the alkalinity and total hardness during the period of study.
\end{abstract}


Calcium and sulfate ions are the dominant cations and anions respectively. It was found 22 taxa of algae identified, dominant by cyanophyta.

Keywords: Thermal, spring, Koya.

\section{Introduction}

Water is the source of life and development on our planet (1). There are large number of water systems in the world in form of oceans, seas, streams, rivers, reservoirs, marshes, lakes and springs (2). A spring is a concentrated ground water flow issuing at the surface as a current of flowing water (3). Thermal springs are characterized by high temperature almost stenothermal, total dissolved solids concentrations are high and their value outweigh that in surface water (4). The organisms in these sorts of environment have been dealt with by many authors. Their ecology and taxonomy have been studied in many parts or the world $(5,6$ and 7). In Iraq such environment have been left behind and a part from (8, 9 and 10), there are no studies on such areas. For further increasing our knowledge, this may be regard as the first attempt for ecology and classification of algae in thermal springs in Erbil province.

\section{Description of the study area}

Erbil province is situated in the north east of Iraq. Erbil covers about 18170 square kilometers. It is bounded to the north-west by the greater zab river and the south-east by lesser zab river. Boundaries extend from longitudinal $43^{\circ} 15^{\prime} \mathrm{E}$ to $45^{\circ} 14^{\prime} \mathrm{E}$ and from latitude $35^{\circ} 27^{\prime} \mathrm{N}$ to $37^{\circ} 24^{\prime} \mathrm{N}$ (11). The climate of Erbil province similar to that of other parts of Kurdistan region and other northern parts of Iraq, which is semiarid and characterized by hot summer and moderately rainy cold winter (12 and 13). Geologically Iraqi Kurdistan is part of the extensive Alpine mountain belt .Three major tectonic zones from north to south were developed including: Thrust zone, high folded zone and low folded zone. The studied area lie within the first two zones (10). Soil formations in the study area were range from mountainous to foothills soil. Mountainous soil formation exists in high folded zone and characterized by darkbrown to black color in upper surface, while its pink and yellowish color in subsurface and consists of lime and about $4-8 \%$ organic matter. In foothills the soils are generally sand with clay (10). Koya district is located $50 \mathrm{~km}$ southern east of Erbil city, the regions boundaries extend from longitude $44^{\circ} 15^{\prime}$ to $44^{\circ} 58^{\prime} \mathrm{N}$ and from latitude $35^{\circ} 49^{\prime}$ to $36^{\circ} 16^{\prime} \mathrm{E}$. Koya covers about 834 Square kilometers (14). The studied area include two thermal springs Mersaid and Jale, the first spring located $30 \mathrm{~km}$ and the second spring $37 \mathrm{~km}$ north-east Koya district Figure (1).

\section{Materials and Methods}


Monthly water samples were taken from Mersaid and Jale springs for a period of July-2007 to February-2008. Air and water temperature measured directly in the field by using precision mercury thermometer, graduated in $0.1 \mathrm{C}^{\circ}$ intervals. $\mathrm{EC}$ and $\mathrm{pH}$ were measured in the field by using (PH-EC-TDS meter, HI 9812, Hanna instrument). Acidity and alkalinity were determined by titration method as described by (15). Total hardness and calcium determined by EDTA titrimetric method, magnesium determined by subtraction of EDTA volume used for calcium titration from EDTA volume used for total hardness, then the result should be multiplied by 0.243 as described by (15). Azide modification of the classical Winkler procedure was used to determine dissolved oxygen, biochemical oxygen demand $\left(\mathrm{BOD}_{5}\right)$ was done after five day incubation at $20 \mathrm{C}^{\circ}$ according to (16). Sodium and potassium cations were determined by Flame Emission Photometer method as described in (16). Sulfate was determined in the present by using the standard turbidimetric procedure as described in (16). The Mohr method was used for determination of chloride content in the studied area as described in (16).Nitrite determined by spectrophotometer method as described by (17), using wave length of $543 \mathrm{~nm}$. Reactive phosphorus was determined by using ascorbic acid reduction method as described by (17). Algal identification carried out by using appropriate identification text books $(18,19$ and 20). 


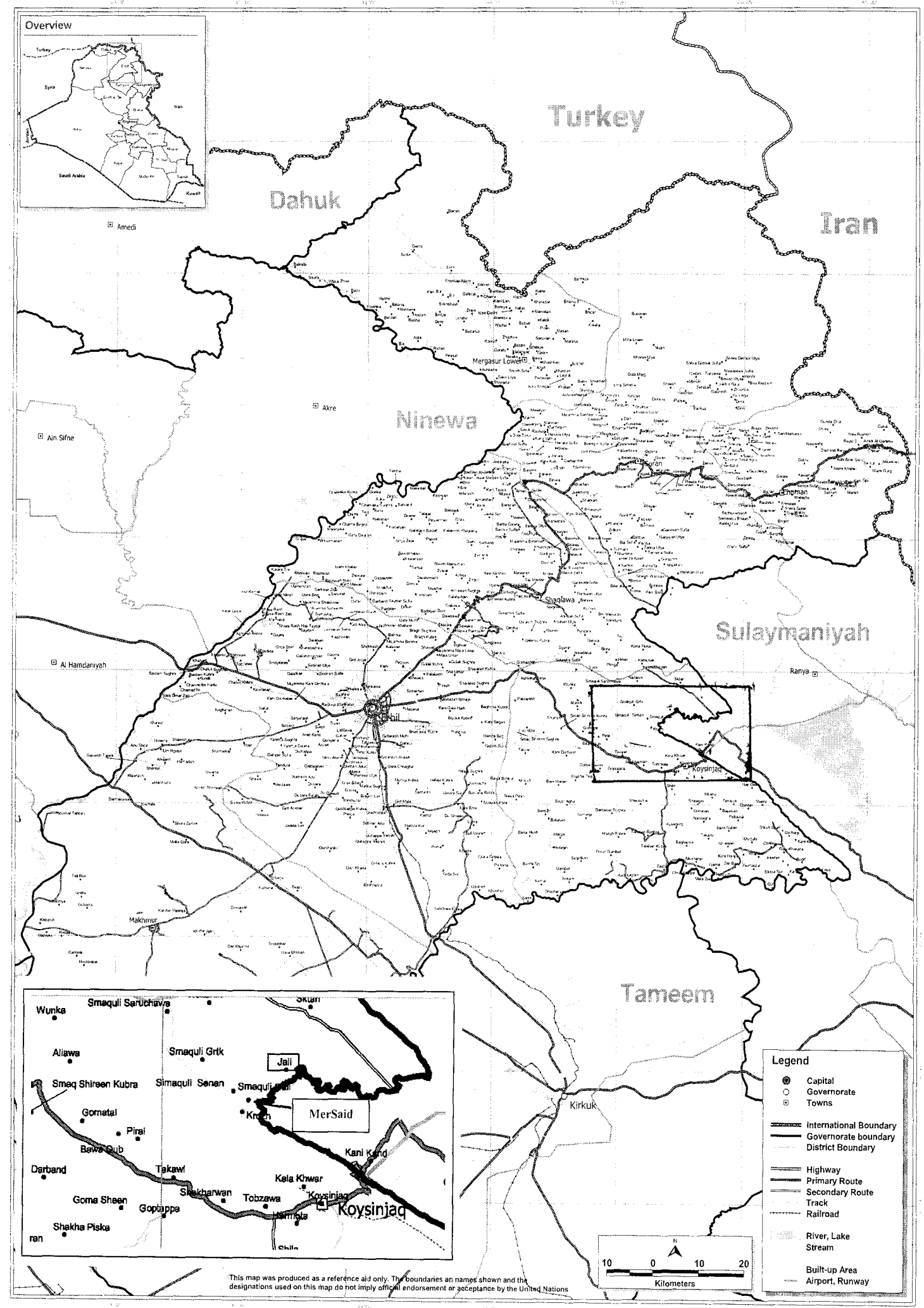

Figure (1): A map showing the site under studied 


\section{Results and discussions}

In spite of existing considerable amount of data on physical and chemical properties of water systems in Iraq (21, 22, 23, 24 and 25), and thermal springs remain almost neglected partly because of their small size and partly because they are scattered in their situations. Still (8, 9 and 10) reported a comprehensive study on thermal springs. In this investigation two thermal springs were chosen in Koya district, Erbil province. The range values of selected parameters recorded at each well during the study period are tabulated on (table1 and 2).

1- Related to air temperature recorded throughout this studied, it seem that the climate of Jale and Mersaid springs is most closely approaches to the Irano-Turanian type. However, the climate characterized by semi-arid type with a wide seasonal range between $\left(8-36.8 \mathrm{C}^{\circ}\right)$. Statement that of (12and 26) seem to confirm the present conclusions. Water temperature ranged from 24 to $35 \mathrm{C}^{\circ}$, therefore all considered springs lies under the categories of hot springs (27) that divided springs to hot temperature ranges from $\left(18-90 \mathrm{C}^{\circ}\right)$ and cold springs where water temperature remain about $9 \mathrm{C}^{\circ}$ as average.

2- The $\mathrm{pH}$ values in the present investigation lies in the alkaline side of neutrality and ranged between 6.9 to 7.3. The obtained values of $\mathrm{pH}$ are considered as usual condition because, generally, in Iraqi Kurdistan region the $\mathrm{pH}$ of water characterized by a shift towards the alkaline side of neutrality due to the geological formation of the area, which composed mainly of $\mathrm{CaCO}_{3}$. Similar conclusion made by ( 8 and 10).

3- The conductivity in this study ranged from 760 to $1380 \mu \mathrm{s} / \mathrm{cm}$. The monthly fluctuations was evident, falling in winter months and rising during summer months due to the rate of discharge of spring waters, although the decreased of mineralization was clear when discharge is increased as stated by (28).

4- In this investigation the alkalinity ranged between 350$395 \mathrm{mgCaCO} 3.1^{-1}$. On the basis of month's variations, the alkalinity of water increased in the rainy months. This phenomenon observed by (29), and stated that when rainfall passes through the soil layers it reacts with carbon dioxide to form carbonic acid, the later react with limestone to produce dissolved calcium and bicarbonate $\left(\mathrm{HCO}_{3}\right)$.

5- During the period of this study the acidity were fluctuated between studied sites and ranged from $14-22 \mathrm{mgCaCO}_{3} \cdot \mathrm{l}^{-1}$. The monthly variations in acidity were evident which increased during summer and autumn months and moderate levels of acidity were detected in winter months. Similar conclusion made by (10).

6- In fresh water, the principle hardness causing ions are calcium and magnesium originated from the sedimentary rocks, the most common being limestone and chalk (2). Concentration of total hardness in the studied area ranged from $300-500 \mathrm{mg} \mathrm{CaCO}_{3} / \mathrm{L}$, these variations throughout this investigation may be related to type and origin of 
water resources, soil properties of the catchment's area, various human activities and effect of several pollutants have been shown influence of the hardness value (30). According to (31), the studied springs water were classified as very hard water because their hardness level $>150 \mathrm{mgCaCO} 3 / \mathrm{L} .7-I n$ fresh water, the principle hardness causing ions are calcium and magnesium originated from the sedimentary rocks, the most common being limestone and chalk (2). Concentration of total hardness in the studied area ranged from 300-500 $\mathrm{mg} \mathrm{CaCO} / \mathrm{L}$, these variations throughout this investigation may be related to type and origin of water resources, soil properties of the catchment's area, various human activities and effect of several pollutants have been shown influence of the hardness value (30). According to (31), the studied springs water were classified as very hard water because their hardness level $>150 \mathrm{mgCaCO} 3 / \mathrm{L}$. Cations in natural water generally dominated by calcium, followed by magnesium, sodium and potassium in order decreasing concentration (32).

7- Dissolved oxygen in this area was zero and BOD5 value varied from 5.8-7.2 $\mathrm{mg} / \mathrm{L}$, this result is similar to that conclusion by (8). High mineralized water may contain high concentrations of organic and inorganic compounds which undergo biochemical and chemical oxidations, and is likely to show depletion of dissolved oxygen (33), similar conclusion made in the studied area.

8- The overall mean value of cations for studied area were as follows calcium-72.55, magnesium-48.95, sodium-4,50 and potassium- 0.48 $\mathrm{mg} / \mathrm{L}$ showing that in Jale and Mersaid springs. Calcium concentration more than magnesium in this survey, this may be attributed to the geological formation of Erbil are which is composed mainly of limestone an solubility of calcite rock which is abundant in the study area is more rapidly than dolomite (34). Sodium salts are generally highly soluble in water, but potassium cations, is not present in high concentration in water, the ratio of potassium to sodium cations is often $1: 10$ or 1:20 (2 and 15). In this investigation have lower value of potassium than sodium according to the general composition of ground water and possibly related to the rocks and soil characteristics of the catchments area (35). The highest value of sodium was $9.1 \mathrm{mg} / \mathrm{L}$ and lowest value was $1.4 \mathrm{mg} / \mathrm{L}$ while highest concentration of potassium was $0.9 \mathrm{mg} / \mathrm{L}$ and lowest concentration was $0.2 \mathrm{mg} / \mathrm{L}$ recorded in this investigation. The clear variations and pulse sodium and potassium during the autumn to winter period may be related to increasing rainfall at that season, following long day summer may be rapidly absorbed by the parched soil. Clearly sodium and potassium are two elements eluted during the rainy season, since they appear in increased concentration in spring water at that time (8).

9- Chloride concentration in this survey varied from 70$280 \mathrm{mg} / \mathrm{L}$.Chloride anions was usually present in natural waters. High concentration occurs in water in contact with chloride geological formation (36). 
10- Sulfate is an abundant ion in the earth crust and its concentration in water range from few milligrams to several thousands milligrams per liter (36). In this investigation the minimum concentration of sulfate was $200 \mathrm{mg} / \mathrm{L}$ in June-2007, while the maximum level observed was 590mg/Lin January -2008. However, it has been demonstrated that sulfate level depend up on solubility of gypsum in ground water and on atmospheric sulfur is oxidized to sulfate and eventually deposited with precipitation in to the ground water (37). Generally Iraqi Kurdistan region inland water usually contain significant amount of sulfate (38).

11- Nitrite level were constantly low in the studied area were lower than $2 \mu \mathrm{g}$ at. $\mathrm{N}-\mathrm{NO}_{2} / \mathrm{L}$. Nitrite was well known as un stable compound nitrogen, which are rapidly oxidized or reducted under normal conditions, consequently the concentration of nitrite is generally low in ground water (8).

12- Phosphorus occurs in natural waters almost solely, it is essential to the growth of organisms (15). Ground water rarely contains more than $0.1 \mathrm{mg} / \mathrm{L}$ phosphorus unless it has passed through soil containing phosphate or has been polluted by organic matter (36). Phosphate values in this investigation varied from $1.0-3.2 \mu \mathrm{g}$ at.P-PO4/L. As shown above phosphate pulse occurred chiefly during the rain season, may be related to elution of soluble phosphate from soil (8). In comparison with other parts of Iraq phosphate level in this survey very similar to (22 and 37 ).

13- Algal studies in Iraq did covered almost all parts of the country and out of 2312 taxa recorded, almost $95 \%$ of the algal flora belonged to Cyanophyta, Chlorophyta and Bacillariophyta (38).

Algae of thermal spring in this investigation were entirely consisting of these groups. Although such studies in Iraq is rare. The results of algal identifications in thermal springs of Erbil may be regarded a preliminary step for further detail survey and this study may stimulate further studies in thermal springs in Iraq. Out of 22 species identified in Jale and Mersaid springs (table 3), 18 species belonged to Cyanophyta, 3 species belonged to Chlorophyta and only one taxa of Charophyta were identified in this area (18,19 and 20). In Mersaid spring chlorophyta not recorded, this is also observed by (9) in which out of seven thermal springs has been studied, chlorophyta was recorded only in one spring. This result may be due to high concentration of sulfate in compare with Jale spring.

It is well known that habitats with calcium-rich waters often support an algal flora dominated by blue-green algae (39). Cyanophyta are considered the most abundant groups in this investigation, and the most dominant species belonging to this group during period of studies 
include: Oscillatoria formosa, O. limnetica, Phormidium tenus, P. valderianum, Spirulina subtillisima and Synechocystis pevalekii (table 4 and 5). Members of Cyanophyta are considered to be normal and most frequent flora of hot springs, throughout the world. They tolerate high temperature $\left(70-72 \mathrm{C}^{\circ}\right)(27)$. Whereas (4) point out that eukaryotic algae can survive up to $\left(55-57 \mathrm{C}^{\circ}\right)$ temperature.

\section{Conclusion}

1) The springs in the studied area considered thermal springs, they characterized by high temperature almost are stenothermal.

2) Springs display a remarkable seasonal stability with respect to $\mathrm{pH}$, varying only \pm 0.4 units.

3) In all investigated springs cations were dominated by calcium followed by magnesium, sodium and potassium in order of decreasing concentration.

4) All of the sources studied can be classified as very hard water.

5) Of the 22 taxa of algae recorded, 18 belonged to Cyanophyta.

Table (1): Physico-chemical variables recorded in Jale spring during the study period.

\begin{tabular}{|c|c|c|c|c|c|c|c|c|c|c|}
\hline Date. & $5-7-$ & $15-8$ & 15-9- & $15-10-$ & $15-11-$ & $15-12-$ & $15-1-$ & $5-2-$ & & Standard \\
\hline Parameters & 2007 & 2007 & 2007 & 2007 & $200-7$ & 2007 & 2008 & 2008 & Mean & deviation \\
\hline $\begin{array}{c}\text { Air Temp } \\
C^{\mathbf{o}}\end{array}$ & 36.5 & 30.5 & 30 & 29.5 & 20.4 & 10.8 & 8 & 15 & 22.5 & 10.50 \\
\hline $\begin{array}{c}\text { Water temp } \\
\mathrm{C}^{\mathrm{o}}\end{array}$ & 25.5 & 25 & 25 & 24 & 24.8 & 24.8 & 24.5 & 25 & 24.8 & 0.43 \\
\hline $\mathrm{pH}$ unit & 7.0 & 7.0 & 7.1 & 6.9 & 7.0 & 7.0 & 7.2 & 7.2 & 7.0 & 0.10 \\
\hline EC $\mu \mathrm{s} . \mathrm{cm}-1$ & 1380 & 1250 & 1200 & 1050 & 1070 & 1060 & 1060 & 1200 & 1158.7 & 119.45 \\
\hline Alk & 360 & 365 & 360 & 370 & 380 & 395 & 397 & 397 & 378 & 16.45 \\
\hline Acidity & 18 & 18 & 18 & 20 & 20 & 18 & 16 & 14 & 17.7 & 1.98 \\
\hline $\mathrm{TH}$ & 300 & 350 & 360 & 390 & 386 & 386 & 300 & 460 & 366.5 & 52.39 \\
\hline DO & 0 & 0 & 0 & 0 & 0 & 0 & 0 & 0 & 0 & 0 \\
\hline BOD5 & 6.0 & 6.4 & 6.2 & 6.3 & 6.5 & 6.1 & 6.0 & 6.5 & 0.206 & 0.20 \\
\hline $\mathrm{Ca}+2$ & 55.31 & 60.12 & 60.92 & 63.32 & 64.12 & 48.06 & 72.12 & 128.25 & 69.0 & 24.91 \\
\hline $\mathrm{Mg}+2$ & 39.38 & 48.62 & 50.56 & 56.39 & 54.94 & 64.44 & 29.17 & 34.03 & 47.19 & 12.03 \\
\hline $\mathrm{Na}+1$ & 6.2 & 6.6 & 6.4 & 7.0 & 8.3 & 8.4 & 8.7 & 9.1 & 7.5 & 1.15 \\
\hline $\mathrm{K}+1$ & 0.5 & 0.6 & 0.5 & 0.6 & 0.8 & 0.7 & 0.8 & 0.9 & 0.675 & 0.14 \\
\hline $\mathrm{Cl}-1$ & 280 & 260 & 280 & 290 & 330 & 290 & 360 & 370 & 307 & 43.98 \\
\hline SO4-2 & 200 & 225 & 250 & 250 & 223 & 225 & 230 & 285 & 236 & 25.45 \\
\hline \begin{tabular}{c|}
$\mathrm{NO} 2 \mu \mathrm{g}$ \\
at.N-NO2/1
\end{tabular} & 1.4 & 1.7 & $1 . .5$ & 1.0 & 0.8 & 1.6 & 1.9 & 2.0 & 1.2 & 0.16 \\
\hline $\begin{array}{l}\text { PO4-3 } \mu \mathrm{g} \\
\text { at.P.PO4/l }\end{array}$ & 2.2 & 2.0 & 1.8 & 2.0 & 1.9 & 1.4 & 1.1 & 1.4 & 1.8 & 0.24 \\
\hline $\mathrm{HCO} 3$ & 439 & 484 & $\varepsilon \wedge \varepsilon$ & \&Ar & $\leq 7 \leq$ & $\leq 01$ & $\varepsilon r q$ & 445 & 461 & \\
\hline
\end{tabular}

Note: All parameters are in $\mathrm{mg} / \mathrm{L}$ unless it stated 
Yadi O. M. Al-Barzingy \& Siraj M. Goran \& Janan J. Toma

Table (2): Physico-chemical variables recorded in Mersaid spring the study period.

\begin{tabular}{|c|c|c|c|c|c|c|c|c|c|c|}
\hline $\begin{array}{c}\text { Date. } \\
\begin{array}{c}\text { Param } \\
\text { eters }\end{array}\end{array}$ & $\begin{array}{l}15-7- \\
2007\end{array}$ & $\begin{array}{l}15-8- \\
2007\end{array}$ & $\begin{array}{l}15-9- \\
2007\end{array}$ & $\begin{array}{l}15-10- \\
2007\end{array}$ & $\begin{array}{l}15-11- \\
200-7\end{array}$ & $\begin{array}{l}15-12- \\
2007\end{array}$ & $\begin{array}{l}15-1- \\
2008\end{array}$ & $\begin{array}{l}5-2- \\
2008\end{array}$ & Mean & $\begin{array}{l}\text { Standard } \\
\text { deviation }\end{array}$ \\
\hline Air Temp Co & 36.8 & 30.0 & 29.5 & 29.5 & 29.5 & 10.8 & 9.0 & 15.0 & 23.7 & 10.49 \\
\hline $\begin{array}{c}\text { Water temp } \\
\mathrm{C}^{\mathrm{o}}\end{array}$ & 35.0 & 30.5 & 30.0 & 31.5 & 31.0 & 31.5 & 31.0 & 32 & 31.56 & 1.52 \\
\hline $\mathrm{pH}$ unit & 7.2 & 7.2 & 7.2 & 7.0 & 7.1 & 6.9 & 7.2 & 7.3 & 7.13 & 0.13 \\
\hline $\mathrm{EC} \mu \mathrm{s} . \mathrm{cm}-1$ & 1090 & 1050 & 980 & 770 & 760 & 780 & 990 & 860 & 910 & 133.52 \\
\hline Alk & 350 & 374 & 370 & 360 & 340 & 350 & 380 & 390 & 364.2 & 17.11 \\
\hline Acidity & 14 & 16 & 17 & 22 & 22 & 17 & 14 & 14 & 17 & 3.33 \\
\hline $\mathrm{TH}$ & 440 & 410 & 405 & 400 & 388 & 450 & 310 & 500 & 412.8 & 54.95 \\
\hline DO & 0 & 0 & 0 & 0 & 0 & 0 & 0 & 0 & 0 & 0 \\
\hline BOD5 & 7.0 & 7.2 & 6.8 & 6.9 & 7.0 & 6.2 & 5.8 & 6.0 & 6.61 & 0.53 \\
\hline $\mathrm{Ca}+2$ & 91.38 & 48.09 & 64.12 & 75.35 & 62.25 & 56.91 & 80.16 & 132.26 & 76.1 & 26.4 \\
\hline $\mathrm{Mg}+2$ & 51.53 & 44.49 & 59.55 & 51.53 & 56.39 & 74.87 & 26.74 & 41.32 & 50.8 & 14.12 \\
\hline $\mathrm{Na}+1$ & 1.4 & 1.5 & 1.8 & 1.5 & 1.6 & 1.7 & 1.7 & 1.5 & 1.5 & 0.13 \\
\hline $\mathrm{K}+1$ & 0.2 & 0.3 & 0.3 & 0.4 & 0.3 & 0.4 & 0.4 & 0.5 & 0.3 & 0.09 \\
\hline $\mathrm{Cl}-1$ & 120 & 120 & 90 & 70 & 90 & 90 & 110 & 120 & 101.2 & 18.8 \\
\hline $\mathrm{SO} 4-2$ & 300 & 310 & 330 & 280 & 315 & 350 & 590 & 512 & 373.3 & 113.4 \\
\hline $\begin{array}{c}\mathrm{NO} 2 \mu \mathrm{g} \text { at. } \mathrm{N}- \\
\mathrm{NO} 2 / \mathrm{l}\end{array}$ & 1.9 & 1.8 & $1 . .9$ & 1.2 & 1.0 & 1.4 & 1.2 & 1.3 & 1.4 & 0.17 \\
\hline $\begin{array}{l}\mathrm{PO} 4-3 \mu \mathrm{g} \\
\text { at.P.PO4/1 }\end{array}$ & 3.2 & 2.8 & 2.5 & 2.4 & 2.3 & 1.9 & 1.0 & 1.6 & 2.2 & 0.55 \\
\hline $\mathrm{HCO} 3$ & 429 & 456 & 451 & 439 & $\leqslant 10$ & 429 & 463 & 475 & 444 & \\
\hline
\end{tabular}

Note: All parameters are in $\mathrm{mg} / \mathrm{L}$ unless it stated 
An Ecological Study On Water To Some Thermal Springs In Koya-Erbil ...

Table (3): list of non-diatoms algal taxa and their distribution in both two springs

\begin{tabular}{|c|c|c|}
\hline Non-diatoms algal taxa & $\begin{array}{l}\text { Jale } \\
\text { spring }\end{array}$ & $\begin{array}{l}\begin{array}{l}\text { Mersaid } \\
\text { spring }\end{array} \\
\end{array}$ \\
\hline $\begin{array}{l}\text { Division: Cyanophyta } \\
\text { Order: Chroococales } \\
\text { 1- Aphanothece nidulans P. Richter }\end{array}$ & + & - \\
\hline 2- Chroococcus minor (ktz.) Naegeli & + & - \\
\hline 3- Gloeocapsa luteofusca Martens & + & - \\
\hline 4- Rhabdoderma arregulare (Naumann) Geitlei & + & - \\
\hline 5- Synechococcus aeruginosus Naegeli & + & - \\
\hline 6- S. elongates Naegeli & - & + \\
\hline 7- Synechocystis pevalekii Ercegevic & + & + \\
\hline $\begin{array}{l}\text { Order: Oscillatoriales } \\
\text { 8- Lyngbya martensiana Meneghini }\end{array}$ & + & - \\
\hline 9- L. perelagens Lemmermann & - & + \\
\hline 10- Oscillatoria ormosa Bory & + & + \\
\hline 11- O. limnetica Lemmermann & + & + \\
\hline 12- O. princes Vaucher & + & - \\
\hline 13- O. pseudogeminata var. unigranulata Biswas & + & + \\
\hline 14- O. terebriformis Agardh & + & + \\
\hline 15- Pormidium tenue (Menegh)Gomi & + & + \\
\hline 16- $P$. valderianum & + & + \\
\hline 17- Pseudoanabaena sp. & + & - \\
\hline 18- Spirulina subtililissima Ktz & + & + \\
\hline $\begin{array}{l}\text { Division: Chlorophyta } \\
\text { Order: Cladophorales } \\
\text { 19- Cladophora sp. }\end{array}$ & + & - \\
\hline $\begin{array}{l}\text { Order: Zygnematles } \\
\text { 20- Mougeotia } \text { sp. }\end{array}$ & + & - \\
\hline 21- Spirogyra sp. & + & - \\
\hline $\begin{array}{l}\text { Division: Charophyta } \\
\text { Order: Charales } \\
\text { 22- Chara vulgaris }\end{array}$ & + & - \\
\hline
\end{tabular}


Table (4): list of non diatoms algal species in Jale spring and their seasonal variation during period of study

\begin{tabular}{|c|c|c|c|c|c|c|c|c|}
\hline Algal species & \multicolumn{8}{|c|}{ Months } \\
\hline Division: Cyanophyta & 7 & 8 & 9 & 10 & 11 & 12 & 1 & 2 \\
\hline Aphanothece nidulaas & - & - & - & + & + & + & - & - \\
\hline Chroococcus minor & - & - & - & + & + & + & - & - \\
\hline $\begin{array}{l}\text { Gloeocapsa luteofusca } \\
\text { Martens }\end{array}$ & - & + & + & + & - & - & - & - \\
\hline Rhabdoderma arregulare & - & - & - & + & + & - & - & - \\
\hline Synechococcus aeruginosus & - & - & - & + & + & + & - & - \\
\hline S. elongatus & + & + & + & + & + & + & + & - \\
\hline $\begin{array}{l}\text { Lyngbya martensiana } \\
\text { Meneghini }\end{array}$ & - & - & - & + & + & + & - & - \\
\hline Oscillatoria formosa & + & + & + & + & + & + & + & + \\
\hline O. limnetica & + & + & + & + & + & + & + & + \\
\hline O. princeps & - & - & - & + & + & - & - & - \\
\hline $\begin{array}{l}\text { O. pseudogeminata var. } \\
\text { unigranulata }\end{array}$ & - & - & - & + & + & + & - & - \\
\hline O. terebriformis & + & + & + & + & + & + & + & $\begin{array}{l}- \\
\end{array}$ \\
\hline Pormidium tenue & + & + & + & + & - & + & + & + \\
\hline$P$. valderianum & + & + & + & + & + & + & + & + \\
\hline Pseudoanabaena sp. & - & - & - & + & + & + & - & - \\
\hline Spirulina subtillisima & + & + & + & + & + & + & + & + \\
\hline Synechocystis pevalekii & + & + & + & + & + & + & + & + \\
\hline \multicolumn{9}{|l|}{ Division: Chlorophyta } \\
\hline Cladophora sp. & - & - & - & - & - & - & - & + \\
\hline Mougeotia sp. & - & - & - & + & + & + & + & + \\
\hline Spirogyra sp. & & & & - & + & + & + & + \\
\hline \multicolumn{9}{|l|}{ Division: Charophyta } \\
\hline Chara vulgaris & + & + & + & + & + & + & + & + \\
\hline
\end{tabular}

+ presence

- absence

\begin{tabular}{||l|l|l|l|l|l|l|l|l||}
\hline \multicolumn{1}{|c|}{ Algal species } & \multicolumn{7}{c|}{ Months } \\
\hline \multicolumn{1}{|c|}{ Division: Cyanophyta } & 7 & 8 & 9 & 10 & 11 & 12 & 1 & 2 \\
\hline Order: Chroococcales & & & & & & & & \\
\hline Synechococcus elongatus & + & + & + & + & + & - & - & - \\
\hline Synechocystis pevalekii & + & + & + & + & + & + & + & + \\
\hline Order: Oscillatoriales & & & & & & & & \\
\hline Lyngbya perelagens & + & + & + & - & - & - & - & - \\
\hline Oscillatoria formosa & + & + & + & + & + & + & + & + \\
\hline O. limnetica & + & + & + & + & + & + & + & + \\
\hline $\begin{array}{l}\text { O. pseudogeminata var. } \\
\text { unigranulata }\end{array}$ & + & + & + & + & + & + & & - \\
\hline O. terebriformis & + & + & + & + & - & - & + & + \\
\hline Pormidium tenue & + & + & + & + & + & + & + & + \\
\hline P. valderianum & + & + & + & - & + & + & + & + \\
\hline Spirulina subtillisima & + & + & + & + & + & + & + & + \\
\hline
\end{tabular}

+ presence

- absence 


\section{References}

1) Helwag, O. J. Water for a growing population: Water supply and ground water issue in developing countries. Water International 25: 217-33. (2000).

2) WHO. Guideline for Drinking Water Quality. $3^{\text {rd. }}$ edition, volume 1 , Recommendation. Geneva. WHO/SDE/WSH/03.04/88. (2004)

3) Clapham, W. B. Natural Ecosystem. Macmillan publishing Co. Inc. Collier Macmillan Publishers.248pp. (1973).

4) Darley, W. M. Algal Biology: a physiological approach. $1^{\text {st }}$ edition. Blackwell Scientific Publication, Oxford. London 168pp. (1982).

5) Odum, E. P. Fundementals of Ecology. $3^{\text {rd }}$ editions. Toppan Printing Co, Singapore. 574 pp. (1973).

6) Wetzel, R. G. Limnology, $2^{\text {nd }}$ edition. Saunders College Publishing. Philadephia. 585pp. (1979).

7) Goldman, C. R and Horn, A. J. Limnology. Mc Grow Hill Book Company. Japan 464 pp. (1983)

8) Ibrahim, A. M. K. A study on algal ecology of springs in Sulaimaniyah province, M. Sc. Thesis, Sulaimaniyah Univ. (1981).

9) Al-Nimma, B. A and Maulood, B. K. A study on the distribution of algae in some thermal springs in Ninevah province, Iraq. J. Ibn AlHaitham. 3(2): 1-9. (1992).

10) Bilbas, A. H. A. Phycolimnological study on some springs within Arbil province. M. Sc. Thesis University of Salahaddin. Iraq (2004).

11) Maulood, B. K and Raoof, I. Y. Further observation on distribution of blue-green algae in Erbil, Kurdistan of Iraq. J. of Duhok University, accepted for publication. (2002).

12) Ahmed, M. S. The total weather and climate brief for Northern Iraq. Agro-Meterology Officer FAO Coordination Office for Northern Iraq: 1-14.(2001).

13) Saeed, M. A. Agrometerology in North of Iraq. Agro-Meteorology Officer FAO Coordination Officer for Northern Iraq: 1-14.(2001)

14) Othman, B. A. Limnology and hygienic status of some water resources within Koya district. M. Sc. Thesis, University of Koya (2008).

15) APHA. Standard Methods for the Examination of Water and Wastewater. $17^{\text {th }}$ edition. Washington. DC. 2005 (1989).

16) Rump, H. H. Laboratory Manual for the Examination of Water Wastewater and Soil. Federal Republic of Germany. 225pp (1999).

17) Parsons, T. R., Maita, Y. and Lalli, C. M. A. A manual of Chemical and Biological Methods for the Seawater Analysis. Pergman Press. Oxford 360pp (1984).

18) Desikachary, T. R. Cyanophyta. Indian Concil of Agriculture Research. 686 pp (1959).

19) Prescott, G. W. Algae of the Western Great Lake Area. W. B. Co. Publ. 977 pp. (1979).

20) Smith, G. M. The Fresh Water Algae of United States. McGrawHill, 917pp. (1950). 
21) Al-Kaisi, K. A. Studies on the algae of a water system in Iraq. Ph.D. Thesis. Univ. College of North Wales. Bangor .U.K.182pp. (1964).

22) Maulood, B. K; Hinton, G. C. F; Saleh, F. A. K; Shaban, A. A and Al-Shahawani, S. M. H. An ecological survey of some aquatic ecosystem in southern Iraq. Tropical ecology. 20 (1):27-39. (1979).

23) Al-Nimma, B. A. B. A study on limnology of the Tigris and Euphrates River. M. Sc. Thesis of University of Salahaddin (1982).

24) Toma, J. J. Limnological study of Dokan Lake, Kurdistan regionIraq. M. Sc. Thesis, University of Salahaddin- Iraq. (2000).

25) Toma, J. J. Study of some physico-chemicalproperties in Shaqlawa Ground water (some wells). Erbil. Iraq. 18(3):9-18.(2006).

26) Guest, E. Flora of Iraq. Vol.1. Ministry of Agriculture, Baghdad. 213pp. (1966).

27) Round, F. E. The Biology of Algae. $2^{\text {nd }}$ edition. Edward Arnold (Publishers). (1975).

28) Maulood, B. K. and Hinton, G. C. F. An ecological study on Serchinar water, chemical and physical aspects. Zanco Sci. J. University of Salahaddin- Iraq. Series A.4 (3):93-117. (1978a).

29) Champion, K. M. and Stark, R. The hydrology and water quality of spring in west-central Florida. Water Quality Monitoring, Southwest Florida Water Management District. An electric media received from http//www.swfw.state.fl.us./ppr/springs.Pdf.

30) Welch, P. S. Limnology. Mcgraw-Hill Book Company. Inc.538.(1952).

31) Sawyer, C. N. and McCarty, P. L. Chemistry for Environmental Enginering. $3^{\text {rd }}$ edition. McGraw-Hill Book Company. U.S.A. 523pp. (1978).

32) Reid, G. K. and Wood, R. D. The Ecology of Inland Water and Estuaries. D. Van Nostand. 485pp. (1976).

33) Ruane, R. J. and Krenel, P. A. Nitrification and other factors affecting nitrogen In the Holston river, Prog.Tech.8:209-224.(1977).

34) Chnaray, M. A. K. Hydrology and Hydrochemistry of KapranBasin Erbil North of Iraq. Ph.D. thesis. University of Baghdad. Iraq. (2003).

35) Al-Sahaf, M. Pollution Control and Water Resources of Iraq. AlHurria Printing House. 307pp.(2003) .

36) Bartram, J. and Balance, R. Water Quality Monitoring. FN spon, an imprint of Chapman and Hall.London.382pp.(1996).

37) Maulood, B. K. and Hinton, G. C. F. Observations of algal flora of Sulaimaniyah area, green and blue green algae. Zanco. Sci. J. of University of Salahaddin- Iraq. 4:55-75.(1978).

38) Maulood, B. K. and Toma, J. J. Check list of algae in Iraq. Sci. Journal of Babylon. Univ. 9(3):1-71.(2004).

39) Kann, E. Systematic and ecology of algae in Austrian mountain stream. Hydrobiol.Suppl. 53(4).405-643.(1978). 